\title{
アジピン酸の抗菌作用 ${ }^{\dagger}$
}

\author{
山本 泰*・軽部則夫*・東 和男* ・好井久雄*
}

\section{Inhibitory Activity of Adipic Acid on Food Spoilage Microorganisms}

(Studies on Growth Inhibition of Food Spoilage Microorganisms for Low Salt Foods Part VI)

\author{
Yasushi Yamamoto*, Norio Karube*, Kazuo HigaShi ${ }^{*}$ and Hisao YoshiI ${ }^{*}$ \\ * Department of Brewing and Fermentation, Tokyo University of \\ Agriculture, 1-1-1, Sakuragaoka, Setagaya-ku, Tokyo 156
}

\begin{abstract}
The inhibitory activity of adipic acid on 10 strains of yeasts and 33 strains of food spoilage bacteria including 6 strains of lactic acid bacteria was investigated. The following results were obtained. (1) Adipic acid protracted the lag phase, extended the mean generation time and decreased the maximum number of cells of Escherichia coli at $\mathrm{pH}$ 5.0. (2) When the $\mathrm{pH}$ of liquid medium was adjusted by adipic acid, the growth of food spoilage bacteria was inhibited between $\mathrm{pH} 4.2$ and 5.2. (3) No significant inhibitory effects of adipic acid on food spoilage bacteria were observed at $\mathrm{pH}$ 6.0. However, growth of the most tested bacteria was inhibited with the concentration below $0.2 \%$ at $\mathrm{pH}$ 5. 0 . (4) Minimum inhibitory concentration of adipic acid on the growth of lactic acid bacteria were $0.4 \sim 1.8 \%$. Therefore, it seemed difficult practically to prevent the growth of lactic acid bacteria completely by the sole use of adipic acid. (5) Growth of yeasts was scarcely affected with the addition of adipic acid.

(Received Jun. 17, 1986)
\end{abstract}

アジピン酸は 1983 年 8 月に 新たに 食品添加物として 指定された酸味料で，その諸性質や加工食品への応用例 については土屋”の解説があり, 現在, デザート食品や 飲料，各種加工食品等に利用されている．著者ら に有機酸類の抗菌性について検討し, 抗菌力は解離度の 低い酸ほど強力であることを報告した。

有機酸類を食品の保存に利用する場合には呈味が問題 となるため，出来るたけ酸味を感じない高い $\mathrm{pH}$ 域で抗 菌力を発揮する有機酸が理想的である. 食品に使用され る有機酸類の中でフジピン酸は酢酸に次いで解離度が低 いため, 他の有機酸に比べて同一浱度で高い $\mathrm{pH}$ を示し, かなり強い抗菌力を有すると考えられる，既に湎類引や 浅漬)への応用も研究されているが，本報では食品の腐 敗に関係する各種の微生物を対象としてアジピン酸の抗 菌作用について検討した.
実 験 方 法

\section{1. 供試菌株}

食品の腐敗に関与する 細菌 27 株, 乳酸菌 6 株, 醅母 10 株を用いた。

\section{2. 試験培地}

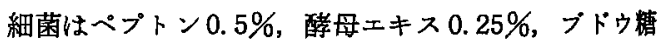
$0.1 \%$ ，乳酸菌はペプトン $1.0 \% ，$ 酵母エキス $0.5 \%$ ，フ ドウ糖 $1.0 \%$ ，醉母はブドウ糖 $5.0 \%$ ，カザミノ酸 $0.4 \%$, 醭母エキス $0.2 \%, \mathrm{KH}_{2} \mathrm{PO}_{4} 0.5 \%$ からなる液体培地を 基礎培地とした。これらの培地で皮膜を形成する菌株に ついては Tween $800.05 \%$ を添加した.

3. 有機酸

アジピン酸は旭化成工業（株）製の食品添加用「フサ ピック」または和光純薬工業（株）製の特級試薬を，比

†低食塩化食品汇打ける腐敗微生物の抑制に関する研究（第6 報）（前報，交献 7)）

* 東京農業大学醇造学科（广 156 東京都世田谷区桜丘 1-1-1) 
Table 1 Growth inhibitory action of adipic acid on Escherichia coli* at pH 5.0

\begin{tabular}{cccc}
\hline \hline $\begin{array}{c}\text { Adipic acid } \\
(\%)\end{array}$ & $\begin{array}{c}\text { Lag time } \\
(\mathrm{min})\end{array}$ & $\begin{array}{c}\text { Mean generation } \\
\text { time (min) }\end{array}$ & $\begin{array}{c}\text { Maximum cell** } \\
(\mathrm{per} \text { ml) }\end{array}$ \\
\hline 0 & 360 & 28.4 & $8.3 \times 10^{7}$ \\
0.2 & 660 & 63.2 & $1.5 \times 10^{7}$ \\
0.4 & 840 & 81.6 & $5.5 \times 10^{5}$ \\
\hline
\end{tabular}

* This strain is stock culture in the Laboratory of Fermented Food Chemistry, Tokyo University of Agriculture.

** Standard plate count

Table 2 Inhibitory $\mathrm{pH}$ value of adipic acid on bacteria

\begin{tabular}{lcc}
\hline \multicolumn{1}{c}{ Strain } & $\begin{array}{c}\text { Inhibitory** } \\
\mathrm{pH}\end{array}$ & $\begin{array}{c}\text { Minimum } \\
\text { of }\end{array}$ \\
growth
\end{tabular}

* Marks indicate stock cultures in the Laboratory of Fermented Food Chemistry, Tokyo University of Agriculture.

** The relation between $\mathrm{pH}$ value and adipic acid concentration of media (mg/ $100 \mathrm{ml}): \mathrm{pH} 5.2(26.2), \mathrm{pH} 5.0(36.8), \quad \mathrm{pH} 4.8$ (53.7), $\mathrm{pH} 4.7$ (65.3), $\mathrm{pH}$ 4.6 (80.5), pH 4.4 (125.2), pH 4.2 (201.5)

*** Media were adjusted by hydrochloric acid. 
較のために使用した酷酸, 乳酸,・クェン酸及び塩酸は市 肘の特級試薬を用いた

4. 生育阻歨 $\mathrm{pH}$

基礎培地に $\mathrm{pH}$ 值が 0.1 間隔で低下するようにアジピ ン酸を添加した培地を用いて既報 ${ }^{2)}$ と同様に試験した。

\section{5. 最小生育阻止濃度}

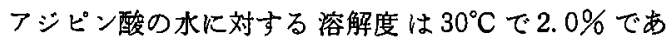
る. そこで, アジピン酸の添加量は0〜2.0\%乙し，既 報 ${ }^{2)}$ の抗菌力の比較試験に準じて pH 5.0,5.5 及び 6.0 における最小生育阻止濃度を求めた。

\section{6. 生育の判定}

生有の判定は $30^{\circ} \mathrm{C} て ゙ 5$ 日間培養後の吸光度 $(660 \mathrm{~nm})$ によった．ま，生菌数は標準寒天平板法で求めた。

\section{結果及び考察}

\section{1. 生充阻害}

有機酸類の抗菌作用 ${ }^{5)}$ は非解離型分子が細胞内へ浸入 することによって発揮されるので，解離度が高くなる中 珄 $\mathrm{pH}$ では殆ど抗菌作用は認められない，そこで，細菌 類に対するアシジン酸の生育阻害作用を知るために $E_{s}$ cherichia coli を用いて pH5.0での生育に及ぼす影響 を調べた (Table 1). pH5.0ではアジピン酸無添加で も最高菌数は $8.3 \times 10^{7} / \mathrm{ml}$ と若干少ないるのの; アジピ ン酸 $0.2 \%$ の添加では誘導期及び平均世代時間が約 2 倍 に延長され，最高菌数は無添加時の $1 / 5$ であった.

更にアジピン酸 $0.4 \%$ 添加では $5.5 \times 10^{5} / \mathrm{ml}$ にとどま り，強力な阻害を受けた．この結果からアジピン酸は E. coli に対しかなり強い抗菌力を有し, 誘導期の延長, 対数期に括ける世代時間の延長，定常期に怙ける最高菌 数低下など生育相のいずれにも影響を及ぼすことが明ら かとなった。

\section{2. 細菌類の生育 $\mathrm{pH}$ に及ぼす影響}

フジピン酸で培地の $\mathrm{pH}$ を調整したときの生育阻止 $\mathrm{pH}$ と塩酸で $\mathrm{pH}$ 調整したときの生育最低 $\mathrm{pH}$ ⿸ Table 2 亿示した. アジピン酸は明らかに生育最低 $\mathrm{pH}$ 上り高 い4.2〜5.2の領域で細菌類の生育を完全に阻止した. アジピン酸, 酢酸 ${ }^{2)}$ の生育阻止 $\mathrm{pH}$ を比較すると, 生育 最低 $\mathrm{pH}$ の高い Alcaligenes, Flavobacterium, Proteus 株を除くグラム陰性の桿菌では後者が高かったが，Bacillus Micrococcus 属等のダラム陽性菌では前者が高 く、アジピン酸は酷酸と同様に高い $\mathrm{pH}$ で細菌類の生育 を阻止することが明らかとなった．従っててジピン酸は 食品の呈味への影響が少ない比較的高い $\mathrm{pH}$ での利用が 可能であることが示唆された。

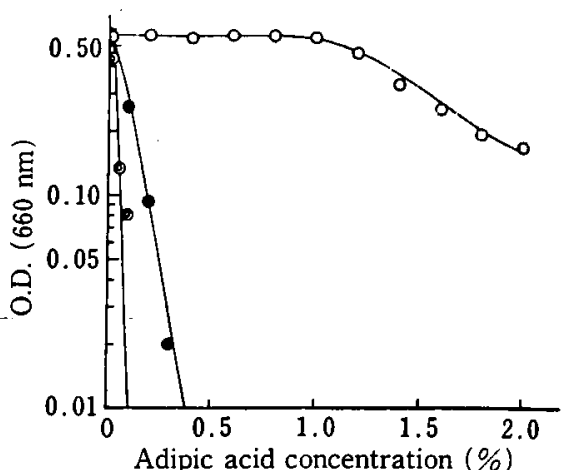

Fig. 1 Effect of adipic acid on growth of Bacillus cereus NRIC 1003

$$
\mathrm{pH}:-0-6.0,-\bullet-5.5,-\odot-5.0
$$

\section{3. 細菌類に対する最小生育阻止濃度}

次に生育阻止に必要なフジピン酸の濃度について検討 した. Fig. 1 は Bacillus cereus の生育に対するアジピ ン酸の濃度の影響を調べたものである. pH 6.0 では最 高溶解濃度の $2.0 \%$ でも生育に及ぼす影響は少ないが, $\mathrm{pH} 5.5$ では0.4\%, pH 5.0 では $0.1 \%$ で完全に生育を 阻止し, $\mathrm{pH}$ の低下に伴って強力な抗菌作用を示した. 細菌類に対するアジピン酸の生育阻止濃度を Table 3 K 示した. pH6.0では Bacillus sphaericusを除くすぺて の株がフジピン酸 $2.0 \%$ で阻止されなかった，しかし， $\mathrm{pH}$ の低下とともに最小生育阻止濃度は低下し, pH 5.0 では比較的酸に対する抵抗力の強いBacillus circulans, Micrococcus freudenreichii, $M$. roseus, Escherichia coli, Salmonella typhimurium が0.3〜0.7\% 示した 他はすべて0.2\%以下であった.

アジピン酸は特に多くの Bacillus p Micrococcus 属 等好気性のグラム陽性菌に対して強い阻止作用を示して いることから，主としてこれらが変敗の原因となり得る

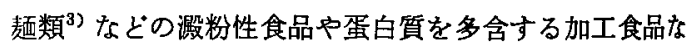
どへの利用が考えられる．アジピン酸の抗菌力を既報》 の結果と比較すれば，酢酸〉アジピン酸〉コハク酸〉釈 酸>リンコ酸〉タェン酸の順となり, 非解離型分子の割 合 (Fig. 2)の高いことから推定されたよらにアシピン酸 は眽酸江次いで強い抗菌力を示すことが確認された，

\section{4. 乳酸菌に対する生育阻害}

乳酸菌は酸に対して比較的強い抵抗力を示す，そこ でこれらに対する作用を知るために酢酸，乳酸及びク エン酸と対比しながらアジピン酸の生育阻止 $\mathrm{pH} 及 ひ ゙$ 及生 育阻止漕度を求めた。 その結果, 生育阻止 pH (Table 4) 
Table 3 Minimum growth inhibitory concentration of adipic acid for bacteria (\%)

\begin{tabular}{|c|c|c|c|}
\hline Strain & $\mathrm{pH} 5.0$ & $\mathrm{pH} 5.5$ & $\mathrm{pH} 6.0$ \\
\hline Bacillus alvei & $0.14(22.6)^{*}$ & $0.9(62.6) *$ & \\
\hline B. cereus & $0.12(22.8)$ & 0.4( & $>2.0(>40.0)^{*}$ \\
\hline B. circulans & $0.30(57.0)$ & $2.0(139.0)$ & \\
\hline B. coagulans & $0.18(34.2)$ & 1.2( & \\
\hline B. firmus & $0.14(22.6)$ & 0.9( & \\
\hline B. licheniformis & $0.04(7.6)$ & 0.4( & $>2.0(>40.0)$ \\
\hline B. macerans & $0.16(30.4)$ & 1.2( & \\
\hline B. megaterium & $0.06(11.4)$ & 0.6( & \\
\hline B. natto & $0.10(19.0)$ & 0.7( & \\
\hline B. pumilus & $0.10(19.0)$ & 0.6( & \\
\hline B. sphaericus & $0.02(3.8)$ & 0.1( & $1.4(28.0)$ \\
\hline B. subtilis & $0.18(34.2)$ & 1.2( & \\
\hline Micrococcus flavus & $0.02(3.8)$ & $0.2 i$ & $>2.0(>40.0)$ \\
\hline M. conglomeratus & $0.06(11.4)$ & 0.4( & $>2.0(>40.0)$ \\
\hline M. epidermidis & $0.06(11.4)$ & $0.5(34.8)$ & $>2.0(>40.0)$ \\
\hline M. freudenreichii & $0.40(76.0)$ & $2.0(139.0)$ & \\
\hline M. luteus & $0.04(7.6)$ & $0.5(34.8)$ & $>2.0(>40.0)$ \\
\hline M. roseus & $0.70(113.0)$ & $>2.0(>139.0)$ & \\
\hline$M$. varians & $0.08(15.2)$ & $1.2(83.4)$ & \\
\hline Staphylococcus aureus & $0.20(38.0)$ & $1.2(83.4)$ & \\
\hline Achromobacter parvulus & $0.15(28.5)$ & $0.5(34.8)$ & $>2.0(>40.0)$ \\
\hline Alcaligenes faecalis & $<0.01 \quad(<1.9)$ & $0.4(27.8)$ & $>2.0(>40.0)$ \\
\hline Escherichia coli & $0.40(76.0)$ & $2.0(139.0)$ & \\
\hline Flavobacterium esteraromaticum & $<0.01 \quad(<1.9)$ & - & $>2.0(>40.0)$ \\
\hline Proteus vulgaris & $<0.01 \quad(<1.9)$ & $0.4(27.8)$ & $>2.0(>40.0)$ \\
\hline Pseudomonas fiuorescens & $0.20(38.0)$ & $1.2(83.4)$ & \\
\hline Salmonella typhimurium & $0.50(95.0)$ & $>2.0(>139.0)$ & \\
\hline
\end{tabular}

* Undissociated molecule concentration $(\mathrm{mg} / 100 \mathrm{ml})$

Undissociated molecule concentration was calculated from the following numerical: Adipic acid concentration $\times$ proportion of undissociated molecule at $\mathrm{pH}$ of media.

はアジピン酸〉酢酸〉乳酸〉クェン酸の順となり，アジ ピン酸は酭酸よりも高い $\mathrm{pH} て ゙$ 乳酸菌の生育を阻止し た.

この傾向は腐敗細菌の場合と同じであり，高い $\mathrm{pH} て ゙$ の生育阻止作用がフジピ酸の特徽と思われる. $\mathrm{pH} 5.0$ に拁ける最小生育阻止濃度 (Table 5) は酢酸くアジピ ン酸く乳酸くクェン酸の順で, 抗菌力は腐敗細菌の場合 と同様に解離度の低い順と一致し，アジピン酸は酿酸に 次いで強い抗菌力を示した. しかし，pH5.0ですべて の乳酸菌の生育を完全に阻止するためには 0.4〜1.8\% のフジピン酸を必要とするため, この酸の単独添加で生 育を阻止することは実際上困難であり, 乳酸菌の完全阻 止には $\mathrm{pH}$ の低下や他の抗菌性を有する物質との併用な
どの手段を講ずる必要がある.

\section{5. 酵母の生育に及ぼす影響}

酵母の至適 $\mathrm{pH}$ 域は 4.0〜6.0で, 酸性 $\mathrm{pH} て ゙$ 旺盛な 生育を示すので, $\mathrm{pH} 5.0 ４ .0$ 及び 3.0 におけるアジピ ン酸の影響を調べた (Fig. 3). Debaryomyces hansenii (当学科䤑造食品化学研究室保存株) は試験した $\mathrm{pH} の$ 範囲内ではほとんど生育に差がなく，いずれの $\mathrm{pH} に お ~$ いてもアジピン酸添加の影響は認められなかった。 た, Hansenulla anomala NRIC 1311, Saccharomyces cerevisiae Kyokai No. 7, 研究室保存の Endomycopsis fibuliger, Candida parakrusei 及び Trichosporon cutaneum の 5 株も同様の結果を示した.

これに対し, Pichia membranaefacience IFO 0115, 


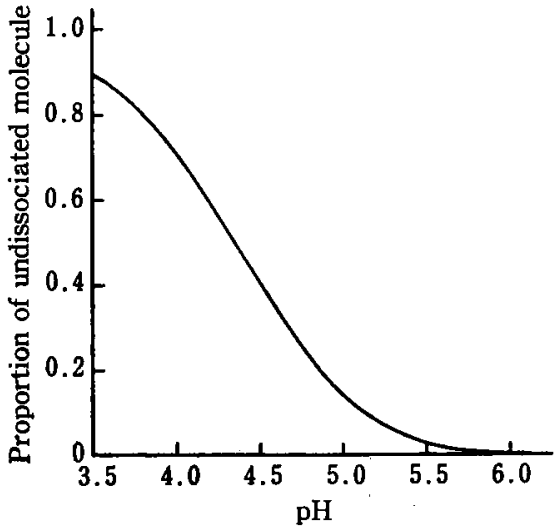

Fig. 2 Relationship between $\mathrm{pH}$ and proportion of undissociated molecule of adipic acid

Proportion of undissociated molecule $(\alpha)$ was calculated from the following numerical formula ${ }^{6}$.

$$
\begin{aligned}
& \frac{1}{\alpha}=1+\frac{\mathrm{K}_{1}}{\left[\mathrm{H}^{+}\right]}+\frac{\mathrm{K}_{1} \mathrm{~K}_{2}}{\left[\mathrm{H}^{+}\right]^{2}} \\
& \mathrm{~K}_{1}=3.90 \times 10^{-5}, \quad \mathrm{~K}_{2}=5.29 \times 10^{-6}
\end{aligned}
$$

Torulopsis famata IFO 1084, Cryptococcus neoformans NRIC 1302 及び研究室保存の Rhodotorula glutinis の 4 株は培地の $\mathrm{pH}$ によって生育差がみられ，アジピ酸 の添加に伴って生育阻害を受けた．しかし，醉母に対す るアジピン酸の生育阻害作用は弱く，アジピン酸の添加 によって醭の生育を阻止することは不可能と判断され た.

以上，アジピン酸はグラム陽性の好気性細菌㹸して かなり強い抗菌力を発揮することから，呈味特性や悢箕 効果などの化学特性 ${ }^{1)}$ ととも食品への利用が有効であ ると判断された.

$$
\text { 要約 }
$$

腐敗細菌 27 株, 乳酸菌 6 株, 酵母 10 侏を対象として アジピン酸の抗菌作用について検討した。

(1) アジピン酸は誘導期及び世代時間の延長，最高菌 数低下のいずれの生育相にも影厡を及ぼすことが分っ た.

（2）細菌類に対する生育阻止 $\mathrm{pH}$ は 4.2 5.2 の範围 にあり, Bacillus や Micrococcus 属などグラム陽性菌に 対しては眽酸の生育阻止 $\mathrm{pH}$ 上りる高い值を示した.

Table 4 Complete inhibitory $\mathrm{pH}$ of organic acid for lactic acid bacteria

\begin{tabular}{lcccc}
\hline \multicolumn{1}{c}{ Strain } & Adipic & Acetic & Lactic & Citric \\
\hline Lactobacillus sake NRIC 1070 & 4.2 & 3.8 & 3.6 & 3.6 \\
Lactobacillus plantarum* & 4.2 & 4.0 & 3.8 & 3.6 \\
Streptococcus faecalis ATCC 8042 & 4.6 & 4.4 & 4.2 & 3.8 \\
S. lactis* & 4.6 & 4.2 & 4.2 & 3.8 \\
Pediococcus hennebergii* & 4.0 & 4.0 & 3.6 & 3.6 \\
Leuconostoc citrovorum* & 4.2 & 4.0 & 4.0 & 3.8 \\
\hline
\end{tabular}

* Marks are stock cultures in the Laboratory of Fermented Food Chemistry, Tokyo University of Agriculture

Table 5 Minimum growth inhibitory concentration of organic acid for lactic acid bacteria at $\mathrm{pH} 5.0(\%)$

\begin{tabular}{llllc}
\hline \multicolumn{1}{c}{ Strain } & \multicolumn{1}{c}{ Adipic } & Acetic & Lactic & Citric \\
\hline Lactobacillus sake & $1.6(304)^{*}$ & $1.4(504)^{*}$ & $>2.0(>140)^{*}$ & $>2.0(>20)^{*}$ \\
Lactobacillus plantarum & $1.0(190)$ & $1.2(432)$ & $1.9(133)$ & $>2.0(>20)$ \\
Streptococcus faecalis & $0.4(76)$ & $0.3(108)$ & $0.7(49)$ & $>2.0(>20)$ \\
S. lactis & $0.6(114)$ & $0.5(180)$ & $1.1(77)$ & $>2.0(>20)$ \\
Pediococcus hennebergii & $1.8(342)$ & $1.4(504)$ & $>2.0(>140)$ & $>2.0(>20)$ \\
Leuconostoc citrovorum & $1.4(266)$ & $1.1(396)$ & $>2.0(>140)$ & $>2.0(>20)$ \\
\hline
\end{tabular}

* Undissociated molecle concentration $(\mathrm{mg} / 100 \mathrm{~m} l)$ 


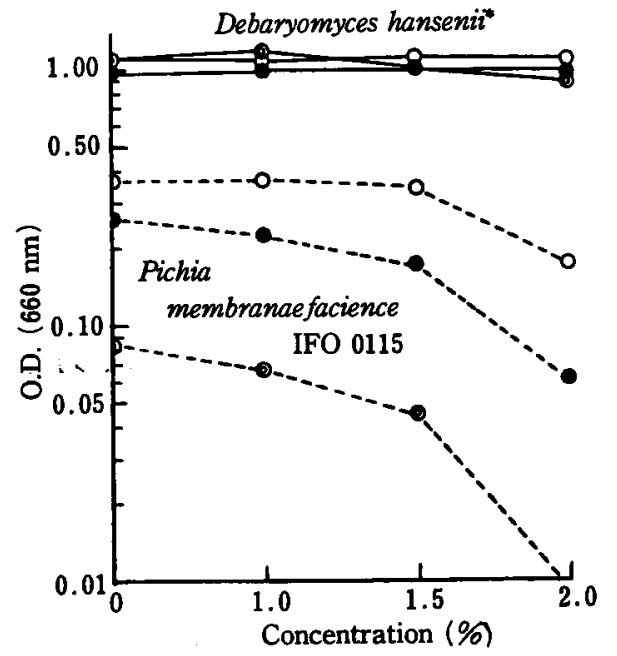

Fig. 3 Effect of adipic acid on growth of yeasts

$\mathrm{pH}:$ ○ $5.0, \bullet 4.0$, 3.0

* Mark indicates a stock culture in the Laboratory of Fermented Food Chemistry, Tokyo University of Agriculture.

(3) 細菌類に対する生育阻止作用は $\mathrm{pH} 6.0$ では殆ん ど認められないが， $\mathrm{pH}$ の低下に伴って阻止濃度が低下 L, pH 5.0では 0.2\% 以下で大半の供試菌の生育を阻止 した.
（4）乳酸菌に対する生育阻止濃度（pH 5.0）は0.4 $1.8 \%$ の間にあり，実際上アジピン酸の単独使用によっ て乳酸菌の生育を完全に阻止することは困難と判断され た.

（5）酵母の生育に及ぼすアジピン酸の作用は弱く，ア ジピン酸の添加によって酵母の生育を阻止することは不 可能であった.

本研究にあたり食品添加用フジピン酸「フサピック」 を提供下さいました坦化成工業株式会社化学品販売第四 部の安川嘉紀氏に感謝の意を表します。

\section{文献}

1) 土谷博道：New Food Industry, 26, (8)，2? (1984).

2）山本 泰・東 和男 - 好井久雄：日食工誌, 31, 525 (1984).

3) 成瀬治己：食品と科学, 堌刊号(2), 88 (1985).

4) 三好英昆：月刊食品，328号， 17 (1985).

5) 野本正雄 - 奈良橋快子 - 新川保太郎：農化，29， 805 (1955).

6) 藤永太一郎・関戸栄一共訳：イオン平衡（化学同 人, 京都), p. 76 (1979).

7) 山本 泰-東 和男 - 好井久雄：日本酸造協会雑 誌, 80, 411 (1985).

（昭和 61 年 6 月 17 日受理） 